\title{
Electroplating of thick hard chromium coating from a trivalent chromium bath containing a ternary complexing agent: a methodological and mechanistic study.
}

\author{
XU, L., PI, L., DOU, Y., CUI, Y., MAO, X., LIN, A., FERNANDEZ, C. and \\ PENG, $C$.
}

This document is the Accepted Manuscript version of a Published Work that appeared in final form in ACS Sustainable Chemistry and Engineering, copyright (C) American Chemical Society after peer review and technical editing by the publisher. To access the final edited and published work see https://doi.org/10.1021/acssuschemeng.0c04529 


\title{
Electroplating of Thick Hard Chromium Coating from a Trivalent Chromium Bath Containing a Ternary Complexing Agent: A Methodological and Mechanistic Study
}

\author{
Lingyun Xu, Liu Pi, Yiheng Dou, Yin Cui, Xuhui Mao, An Lin, Carlos Fernandez, \\ and Chuang Peng
}

\begin{abstract}
:
Trivalent chromium electroplating is considered a greener alternative to hexavalent chromium electroplating. However, the electrochemical reduction of $\mathrm{Cr}(\mathrm{III})$ in aqueous solution is extremely unstable and the thickness of the coating can hardly grow beyond 10 $\mu \mathrm{m}$, which limits its industrial applications. We herein report a trivalent chromium bath containing a ternary complexing agent, which yields bright and uniform chromium coatings with thickness exceeding $30 \mu \mathrm{m}$, as well as high hardness and corrosion resistance. The electroplating behaviors and first principal calculations reveal that the $\mathrm{Cr}(\mathrm{II})$ intermediate plays a vital role in sustained electroplating in $\mathrm{Cr}$ (III) baths. The composition of complexing agents has a profound effect on the geometry and electron accepting ability of the $\mathrm{Cr}$ (II) complex ions. The failure to grow thick $\mathrm{Cr}$ coating is attributed to the accumulation of inactive hydroxo-bridged complexes. In the bath with ternary complexing agent, the $\mathrm{Cr}(\mathrm{II})$ complex ions are $\mathrm{dsp}^{3}$ or $\mathrm{dsp}^{2}$ hybridized with high electron affinity, which can be readily reduced to metallic $\mathrm{Cr}$. The bath also shows a strong competitive ligand-binding effect that renders $\mathrm{Cr}$ (II) to preferentially bind with an organic ligand rather than a hydroxy ligand. Furthermore, the planar geometry of $\mathrm{dsp}^{2}$ hybridization does not favor the formation of hydroxo-bridged complexes because of the steric hindrance effect. The above merits of the ternary complexing agent lead to sustained electroplating, and thick $\mathrm{Cr}$ coatings are obtained.
\end{abstract}

KEYWORDS: trivalent chromium electroplating, complexing agent, steric hindrance, electron affinity, divalent intermediates

\section{INTRODUCTION}

Hard chromium (HC) coating has been widely used for protective and functional purposes in mechanical parts of aerospace, automotive, and petrochemical industries due to its multiple desired properties, such as high hardness, low friction coefficient, superior wear, and corrosion resistance. ${ }^{1-3}$ The thickness of $\mathrm{HC}$ coating is usually in the range from several tens 
to several hundreds of micrometers. ${ }^{4,5}$ Despite its widespread use, most high-quality HC coatings are electrodeposited from aqueous electroplating baths containing highly toxic hexavalent chromium, i.e., $\mathrm{Cr}(\mathrm{VI})$. With the increasing environmental concerns, strict regulations, or complete ban has been or will be enacted on hexavalent chromium electroplating worldwide. 6,7 As a more environmentally benign alternative, trivalent chromium electroplating (TCE) has been studied extensively in recent decades. ${ }^{8,9}$

Despite the success in depositing thin decorative $\mathrm{Cr}$ coatings $(0.1-2 \mu \mathrm{m})$, it remains a challenge as how to obtain highquality thick $\mathrm{HC}$ coatings from a $\mathrm{Cr}$ (III) bath. The low current efficiency or high overpotential is commonly observed which is attributed to the formation of stable coordination of $\mathrm{Cr}$ (III) with water molecules. Furthermore, the deposition rate suffers from a rapid decrease over time and the obtained maximum coating thickness is generally less than $10 \mu \mathrm{m},{ }^{10-12}$ making the product unsuitable for functional applications. It is postulated that the fast deactivation is mainly due to the following reasons. During the electrodeposition process, hydrogen evolution reaction causes a local $\mathrm{pH}$ increase near the cathode, resulting in the formation of an electroactive intermediate, i.e., hydroxo-complexed chromium(II) ions. ${ }^{13}$ -15 These complex ions can be easily converted into inert hydroxy-bridged compounds through an olation reaction and hinder the continuous reduction of $\mathrm{Cr}(\mathrm{III}) .{ }^{16}$ As a result, both the current efficiency and deposition rate drop rapidly and the coating thickness can hardly increase.

Numerous endeavors have been made to deposit $\mathrm{HC}$ by changing the solution chemistry and process conditions. Ionic liquids (ILs) have attracted increasing interest as media for TCE to avoid parasitic hydrogen evolution. ${ }^{17-20}$ Although the electrochemical window of ILs is wide, its high viscosity, poor conductivity, and high cost limit its practical applications. Other endeavors have been devoted to electrodeposition of $\mathrm{Cr}$ alloys (e.g., $\mathrm{Cr}-\mathrm{C}, \mathrm{Cr}-\mathrm{Ni}$, and $\mathrm{Cr}$ $-\mathrm{Co}$ ) from aqueous solutions containing chromium(III) and other reducible components. ${ }^{21-24}$

-However, the properties of these composite coatings are only similar to certain aspects of $\mathrm{HC}$. There is no alloy reported in literature that could adequately replace $\mathrm{HC}$ in overall performances.

Alternatively, the use of multicomponent complexing agents is regarded as the most effective and convenient approach for improving the properties of aqueous plating bath as well as the quality of the deposits. ${ }^{25-31}$ The electrolyte containing more than one ligand may strengthen the ligand exchange reaction and regulate the overpotential for metal deposition, which ultimately improves the stability and efficiency of electroplating. This method has also been studied for $\mathrm{Cr}$ (III) plating. For instance, $\mathrm{Cr}$ (III) baths containing both formic acid and urea have yielded thick $\mathrm{Cr}$ coatings with a rather high current efficiency. ${ }^{32-34}$ Nevertheless, these deposits commonly show inadequate properties such as hardness and corrosion resistance, making them unsuitable for tribological and anticorrosion applications. While the search for optimum bath composition for $\mathrm{HC}$ electroplating is mostly intuitive, the underlying mechanism also remains debatable. ${ }^{35-37}$ The role of divalent chromium intermediates in the electrode position reaction has not been elucidated. Moreover, the mechanism of depositing thick uniform coating from $\mathrm{Cr}$ (III) baths containing a multicomponent complexing agent is yet to be elucidated. In this paper, a trivalent $\mathrm{Cr}$ bath containing ternary complexing agent is proposed for hard chromium electrode position. The performances of the plating solution and the chromium deposit are investigated and compared with those in the literature. Furthermore, the role of the $\mathrm{Cr}$ (II) intermediates is comprehensively studied through first-principles calculations, and the mechanism for depositing thick uniform high-quality chromium coatings is discussed. 


\section{EXPERIMENTAL SECTION}

Electrodeposition of $\mathrm{Cr}$. The basic composition and concentration of the trivalent chromium bath containing ternary complexing agent are summarized in Table 1 . All solutions were prepared using deionized water and AnalaR grade chemicals. The $\mathrm{pH}$ was adjusted to 1.5 by addition of $\mathrm{H}_{2} \mathrm{SO}_{4}$ or $\mathrm{NaOH}$. After mixing of all components, the solution was heated at $60^{\circ}$ $\mathrm{C}$ for $20 \mathrm{~min}$, then cooled and aged for $24 \mathrm{~h}$. The two-electrode electroplating was carried out in a temperature-controlled glass cell without separation of electrode compartments. Dimensionally stable Ti/IrO ${ }_{2}$ anode (DSA) and brass $\left(\mathrm{S}=0.1 \mathrm{dm}^{2}\right)$ were used as the anode and cathode, respectively. The surface of the brass substrate was polished with magnesium oxide and then rinsed with hydrochloric acid solution and distillate water. Prior to galvanostatic chromium plating, the optimum current density range of the plating bath was determined using a $267 \mathrm{~mL}$ standard Hull Cell at a cell current of 10 A for a duration of 10 min. A brass plate $(75 \times 100 \mathrm{~mm})$ served as the substrate, and the length of bright $\mathrm{Cr}$ covered area was measured after electrolysis. The corresponding current density was evaluated by the following empirical equation (German standard DIN50957, eq 1): ${ }^{36,38}$

$$
j(x)=I(5.10-5.24 \lg x)
$$

where $x$ indicates the distance $(\mathrm{cm})$ along the cathode from the high current edge, $j(x)$ is the local current density $\left(\mathrm{A} / \mathrm{dm}^{2}\right)$ at distance $\mathrm{x}$, and $\mathrm{I}$ is the total electrolytic current $(\mathrm{A})$. The galvanostatic chromium deposition was carried out at $30{ }^{\circ} \mathrm{C}$ for different duration time of 2 , $5,10,15,20,25,30$, and $35 \mathrm{~min}$.

Characterization. The thickness of the Cr coatings deposited on brass substrate was measured by a TT260 thickness detector (Shidai Instrument, China) based on the Eddy current principles. The current efficiency of chromium electrodeposition was calculated as the ratio between the experimental and theoretical weight uptakes after electrodeposition. Vickers hardness $(\mathrm{HV})$ of chromium coatings were evaluated by a microhardness tester with a load of $100 \mathrm{~g}$. The surface morphology of deposits was studied by SIGMA scanning electron microscope (Zeiss, German). The crystal structure of the coating was characterized by a SHIMADZU XRD-6000 diffractometer (Japan) employing $\mathrm{Cu} \mathrm{K}$ radiation $(\lambda=0.154 \mathrm{~nm}$ ) with $2 \theta$ canning step of $2^{\circ} / \mathrm{min}$ and angle range of $10^{\circ} \sim 80^{\circ}$. Chemical composition of the chromium deposit was examined using an Aztec Energy X-Max energy-dispersive spectrometer (Oxford Instruments, UK) with an acceleration voltage of $20 \mathrm{kV}$.

Electrochemical Measurements. Electrochemical measurements were conducted in a threeelectrode cell using a CHI660D electrochemical workstation (Chenhua, China). A platinum foil $(1 \times 1 \mathrm{~cm})$ or the Cr-coated brass sheet $(1 \times 1 \mathrm{~cm})$ served as the working electrodes for the polarization curve test of the bath and corrosion behavior characterizations of the $\mathrm{Cr}$ coatings, respectively. The counter and reference electrode were a large area platinum foil and a saturated calomel electrode (SCE), respectively. Cathodic polarization was performed in the $\mathrm{Cr}(\mathrm{III})$ baths at a scan rate of $5 \mathrm{mV} / \mathrm{s}$. The Tafel plot was obtained in $3.5 \% \mathrm{NaCl}$ aqueous solution at a scan rate of $2 \mathrm{mV} / \mathrm{s}$ from -0.3 to $0.3 \mathrm{~V}$ versus the open circuit potential (OCP). Electrochemical impedance measurement was also carried out in $3.5 \% \mathrm{NaCl}$ aqueous solution and recorded in the frequency range from 10-2 $\sim 105 \mathrm{~Hz}$ with an AC amplitude of $5 \mathrm{mV}$. All experiments were carried out at room temperature. 
Density Functional Theory (DFT) Calculations. Geometry optimizations and single-point energy calculations of the molecular structures were performed with the Gaussian16 A03 program at the BP86/def-SVP level of theory. Taking into account the solvation effect of water, solvent model density (SMD) continuum models were utilized to simulate the coordination geometry of $\mathrm{Cr}^{2+}$ with four typical complexing agents of oxalate $\left(\mathrm{HOOCCOO}^{-}\right.$, $\mathrm{OA}-\mathrm{H})$, tartrate $\left(\mathrm{HOOC}(\mathrm{CHOH})_{2} \mathrm{COO}^{-}, \mathrm{TA}-\mathrm{H}\right)$, formate $\left(\mathrm{HCOO}^{-}, \mathrm{FA}-\mathrm{H}\right)$, and urea $\left(\mathrm{CO}\left(\mathrm{NH}_{2}\right)_{2}, \mathrm{U}-\mathrm{H}\right)$. The resulting stable aquo-complexed chromium(II) are denoted as $\left[\mathrm{Cr}(\mathrm{OA}-\mathrm{H})\left(\mathrm{H}_{2} \mathrm{O}\right)_{5}\right]+,\left[\mathrm{Cr}(\mathrm{TA}-\mathrm{H})-\left(\mathrm{H}_{2} \mathrm{O}\right)_{5}\right]+,\left[\mathrm{Cr}(\mathrm{FA}-\mathrm{H})\left(\mathrm{H}_{2} \mathrm{O}\right)_{5}\right]^{+}$, and $\left[\mathrm{Cr}(\mathrm{U}-\mathrm{H})\left(\mathrm{H}_{2} \mathrm{O}\right)_{5}\right]^{2+}$, respectively. After deprotonation, the above four complexes are transformed to $[\mathrm{Cr}(\mathrm{OA})$ $\left.\left(\mathrm{H}_{2} \mathrm{O}\right)_{5}\right],\left[\mathrm{Cr}(\mathrm{TA})\left(\mathrm{H}_{2} \mathrm{O}\right)_{5}\right],\left[\mathrm{Cr}(\mathrm{FA}-\mathrm{H})\left(\mathrm{H}_{2} \mathrm{O}\right)_{4} \mathrm{OH}\right],\left[\mathrm{Cr}(\mathrm{U}-\mathrm{H})\left(\mathrm{H}_{2} \mathrm{O}\right)_{4} \mathrm{OH}\right]^{+}$, as revealed by the DFT calculations.

\section{RESULTS AND DISCUSSION}

Electrodeposition of Thick Hard Chromium Coating. As reported, both the current density and deposition time are important process parameters for trivalent chromium electroplating. 13 The optimum current density range of the plating bath was determined by Hull cell tests. Figure 1a shows a Hull cell panel plated with chromium coating from the bath containing a ternary complexing agent of oxalic acid, tartaric acid, and urea (denoted as OA-TA-U). The shiny $\mathrm{Cr}$-covered area on the left shows that chromium was successfully electroplated on the brass sheet and the optimum current density range was identified between 30 and $55 \mathrm{~A} /$ $\mathrm{dm}^{2}$ according to eq 1 . Thus, a reasonable current density of $35 \mathrm{~A} / \mathrm{dm}^{2}$ was chosen for the subsequent experiments. Figure $1 \mathrm{~b}$ shows that the thickness of $\mathrm{Cr}$ coating increases linearly with deposition time within $15 \mathrm{~min}$. Beyond $15 \mathrm{~min}$, the coating thickness also increased as the plating proceeded, though at a slower rate. Hard chromium with a thickness exceeding $30 \mu \mathrm{m}$ was obtained with a moderate deposition time of $35 \mathrm{~min}$. The rate of chromium deposition was reported to diminish rapidly over deposition time and usually after several minutes of electrolysis no mass gain was observable. ${ }^{39}$ Nevertheless, the deposition rate in this work did not decrease significantly in the first $30 \mathrm{~min}$, and thick deposits could be obtained upon prolonged deposition time. An obvious decline in deposition rate did occur at $30 \mathrm{~min}$, and the coating barely grew after $35 \mathrm{~min}$. The morphology of the $\mathrm{Cr}$ coating (Figure 1c) indicates that the Cr(III) electroplating features a typical nucleation-growth mechanism. Within the first 2 min of plating, ultrathin $\mathrm{Cr}$ layer grew uniformly on the substrate. From 5 to $20 \mathrm{~min}$, the existing crystal nuclei grew over time and new ones were formed. Concomitantly, microscopic fissures were observed on the $\mathrm{Cr}$ deposits. As the plating proceeded, the coating morphology at 25 and 30 min became similar to that observed at $5 \mathrm{~min}$, suggesting that large nodular-like structures $(20 \mathrm{~min})$ were covered by newly grown fine grains and the coating defects were significantly leveled off. This was due to the relatively low nucleation and growth rate, which was consistent with the observed rate decline in Figure 1b. At $35 \mathrm{~min}$, the fissures were mostly healed and the coating became dense and uniform. Meanwhile an obvious decrease in current efficiency was also observed (Figure 1b). Figure 1d shows the crosssection microstructure of the coating and the corresponding elemental mapping images of $\mathrm{Cu}$ and $\mathrm{Cr}$, confirming that a homogeneous and dense chromium coating with a favorable thickness of ca. $30 \mu \mathrm{m}$ was successfully obtained after $30 \mathrm{~min}$ of electroplating. Compared with the rapid growth of $\mathrm{Cr}$ coating in hexavalent baths (typically $0.2-0.6 \mu \mathrm{m} / \mathrm{min}$ ), ${ }^{39}$ the time duration for electroplating in the $\mathrm{Cr}(\mathrm{III})$ bath was notably prolonged. 
Characterization of the Plating Solutions and the Cr Coatings. To further explore the practicality of the ternary complexing agent bath for HC plating, both the solution and the deposits were characterized and compared with the following three baths: (1) binary complexing agent bath containing oxalic acid and tartaric acid (denoted as OA-TA), (2) hard chrome bath containing formic acid and urea (FAU), ${ }^{32-34}$ and (3) decorative chrome bath containing formic acid (FA). ${ }^{40,41}$ Detailed composition of the four baths is listed in Table S1. The key parameters of the plating process and the Cr coatings are compared in Table 2. The optimum current density ranges for the baths of OA-TA, FA-U, and FA were determined by Hull cell tests (Figure S1), and thus the Cr plating was carried out at 45, 20, and $5 \mathrm{~A} / \mathrm{dm}^{2}$, respectively. The $\mathrm{Cr}$ (III) plating bath with the OA-TA-U ternary complexing agent exhibits the highest deposition rate of $1.01 \mu \mathrm{m} / \mathrm{min}$. Its current efficiency was $19.18 \%$, higher than that for a typical hexavalent chromium electrodeposition $(12 \% \sim 18 \%) .{ }^{39}$ FA-U solution shows even higher current efficiency of $28.12 \%$ but both the deposition rate and the coating thickness are lower. Bath solution with FA alone exhibits minimal deposition rate and the coating could barely grow after $10 \mathrm{~min}$ of plating. The OA-TA-U solution not only yields the highest coating thickness but also the highest coating hardness of $866 \mathrm{HV}$ (Figure S2). SEM and optical images (Figure $2 \mathrm{a}-\mathrm{d}$ ) show the coating obtained with the OA-TA-U solution exhibits smooth and shiny metallic appearance as well as uniform and dense micromorphology (Figure 2a). However, the coatings deposited from OA-TA or FA-U solution exhibited a rough surface and nodular structure with microscopic cracks (Figure $2 \mathrm{~b}, \mathrm{c})$. Moreover, both coatings show a dull and dark surface, caused by a high surface roughness or the presence of impurities such as carbon and sulfur. ${ }^{42,43}$ The thin coating deposited from FA (Figure 2d) shows typical features of decorative chromium coating with shiny metallic luster, good adhesion, and low roughness. The homogeneous microstructure of this coating may also derive from its low thickness. Despite the appealing appearance, the extremely thin $\mathrm{Cr}$ coating is not suitable for anticorrosion and tribological applications. Therefore, the $\mathrm{Cr}$ coating deposited from the OATA- U solution is the only one to meet the two important requirements of hard chromium, i.e., sufficient thickness and desired appearance and microstructure. The crystal structure of the coatings was further probed by X-ray diffraction (XRD). As shown in Figure 2e, three peaks at $42.2^{\circ}, 49.2^{\circ}$, and $72.2^{\circ}$ are assigned to the (111), (200), and (220) facets of the brass substrate. ${ }^{44}$ The presence of these sharp substrate peaks in the samples from FA, FA-U, and OATA baths can be attributed to (1) the thickness of the coating being less than the penetration depth of the X-ray or (2) the presence of microscopic cracks within the $\mathrm{Cr}$ coatings. In contrast, these substrate peaks can be hardly detected in the sample from the OA-TA-U bath, confirming that high-quality thick $\mathrm{Cr}$ coatings were obtained. The magnified spectrum of OA-TA-U in Figure $2 \mathrm{f}$ shows a broad peak located at around $45^{\circ}$. This peak is attributed to amorphous/microcrystalline $\mathrm{Cr}$ (110), which is a typical feature of $\mathrm{Cr}$ coating electrodeposited from trivalent chromium baths. ${ }^{34}$ For the FA-U sample, the diffraction peaks of $\mathrm{Cr}$ are sharper, indicating a higher degree of crystallinity compared to the OA-TA-U sample. The higher crystallinity is probably a result of increased crystal size which leads to reduced compactness of the coating. The linear sweep voltammetry (LSV) curves (Figure 3a) reveal that the electroreduction process in $\mathrm{Cr}$ (III) baths consist of three regions, in good agreement with the literature. 15 In the first potential region, from 0 to $-0.6 \mathrm{~V}$ for the OA-TA-U and OA-TA baths and 0 to $0.75 \mathrm{~V}$ for the FA-U and FA baths, no cathodic current is detected because there is no Faradaic reaction and the electrode is ideally polarized. In the second region, from -0.6 to $-1.1 \mathrm{~V}$ for the OA-TA-U and OA-TA baths and -0.75 to $-1.3 \mathrm{~V}$ for the FAU and FA baths, the current increases with potential until reaching a limiting diffusion current plateau, indicating that $\mathrm{Cr}(\mathrm{III})$ reduction has occurred. At potentials more negative than $-1.1 \mathrm{~V}$ and $1.3 \mathrm{~V}$, respectively, a rapid increase of the curve slope is observed for all electrolytes and the main cathodic reaction is hydrogen evolution. 
Compared with the baths of FA-U and FA, an obvious increase of the limiting diffusion current density was observed in the LSV curves of OA-TA-U and OA-TA, suggesting that higher current density can be employed in galvanostatic chromium plating, which is consistent with the results in Table 2. However, because of the lower current efficiency, more severe hydrogen evolution would occur in the OA-TA bath. The corrosion resistance of the coatings was evaluated with potentiodynamic polarization test coupled with electrochemical impedance measurement. The corrosion current density (Icorr) and corrosion potential (Ecorr) are calculated from the intercept of the Tafel slopes (Figure 3b) and listed in Table S2. Among the four samples, chromium deposited from a OA-TA-U bath exhibits the lowest value of Icorr and thus the lowest corrosion rate. The sample deposited from the FA bath exhibits the most positive value of Ecorr, which can be interpreted as a mixed potential of chromium and brass corrosion resulting from the incomplete coverage of the substrate by the ultrathin chromium coating. All the four samples exhibit two capacitive loops in the Nyquist plots (Figure 3c and inset). The bode plots (Figure S3) reveal two time constants for the thin Cr coating from the bath containing FA alone. In contrast, the rest of the three samples show three time constants because the defects (e.g., micropores and microcracks) result in more complex reaction interfaces in thicker chromium coatings. ${ }^{45,46}$ Therefore, two different equivalent circuits (Figure $3 \mathrm{~d}, \mathrm{e}$ ) are used to fit the experimental data of the thick and thin chromium coatings, respectively. In both models, $\mathrm{RS}$ is the electrolyte resistance. $\mathrm{CPE}_{\mathrm{dl}}$ and $\mathrm{R}_{\mathrm{ct}}$ are the double layer capacitance and the charge transfer resistance of the corrosion reaction. $R_{1}$ and $C P E_{1}$ represent the resistance and capacitance of an oxide layer. $\mathrm{R}_{2}$ and $\mathrm{CPE}_{2}$ are the resistance and capacitance associated with porous structure and defects of the coating. The Warburg impedance $\mathrm{W}$ is a diffusion impedance element. The fitted curves from the respective equivalent circuit show high conformity with the experimental data (Figure S4). The simulated equivalent circuit parameters for the four samples are listed in Table S3. The coating deposited from the OA-TAU bath exhibits significantly higher $\mathrm{R}_{\mathrm{ct}}$ value than the other three, verifying its better corrosion resistance.

Mechanism for Deposition of Thick Chromium Coatings from $\mathrm{Cr}$ (III) Baths. The above characterization indicates that the bath containing an OA-TA-U ternary complexing agent has clear advantages in depositing thick $\mathrm{Cr}$ coatings. The underlying mechanisms need to be further elucidated. In aqueous solution, $\mathrm{Cr}^{3+}$ is coordinated with six water molecules to form $\left[\mathrm{Cr}\left(\mathrm{H}^{2} \mathrm{O}\right)^{6}\right]^{3+}$ which exhibits regular-octahedron structure with $\mathrm{Cr}^{3+}$ located at the center. The electrons on the cathode can hardly reach the inner d-orbits of $\mathrm{Cr}^{3+}$ during the electrodeposition because of the surrounding water molecules. ${ }^{35,47}$ Ionic complexing agents ( $\mathrm{L}^{-}$), such as $\mathrm{HCOO}^{-}, \mathrm{HOOCCOO}^{-}$, and $\mathrm{C}_{2} \mathrm{H}_{4} \mathrm{NO}_{2}{ }^{-}$, can compete with water molecules to coordinate with $\mathrm{Cr}^{3+}$, forming cocoordinated $\left[\mathrm{CrL}\left(\mathrm{H}_{2} \mathrm{O}\right)_{5}\right]^{2+}$. The large-sized ionic ligand generates a steric hindrance effect so $\left[\mathrm{CrL}\left(\mathrm{H}_{2} \mathrm{O}\right)_{5}\right]^{2+}$ presents an irregularoctahedron structure, in which the distances between $\mathrm{Cr}^{3+}$ and the surrounding water molecules are expanded (eq 2). Therefore, upon addition of the ligand, $\mathrm{Cr}^{3+}$ ions gain immediate contact with the cathode, i.e., easier to receive electrons from the cathode. ${ }^{36}$ Previous studies ${ }^{10,37}$ have suggested that electrodeposition of chromium involves two consecutive steps: one-electron reduction of trivalent chromium complex $\left[\mathrm{Cr}(\mathrm{III}) \mathrm{L}\left(\mathrm{H}_{2} \mathrm{O}\right)_{5}\right]^{2+}$ (eq 3), followed by a twoelectron reduction of the as-formed divalent chromium complex $\left[\mathrm{Cr}(\mathrm{II}) \mathrm{L}\left(\mathrm{H}_{2} \mathrm{O}\right)_{5}\right]^{+}$to metallic $\mathrm{Cr}$ (eq 4). Concomitantly, hydrogen evolution reaction in eq 5 occurs at the same applied potential, leading to an increase of local $\mathrm{pH}$. 


$$
\begin{aligned}
& {\left[\mathrm{Cr}(\mathrm{III})\left(\mathrm{H}_{2} \mathrm{O}\right)_{6}\right]^{3+}+\mathrm{L}^{-} \rightarrow\left[\mathrm{Cr}(\mathrm{III}) \mathrm{L}\left(\mathrm{H}_{2} \mathrm{O}\right)_{5}\right]^{2+}+\mathrm{H}_{2} \mathrm{O}} \\
& {\left[\mathrm{Cr}(\mathrm{III}) \mathrm{L}\left(\mathrm{H}_{2} \mathrm{O}\right)_{5}\right]^{2+}+\mathrm{e}^{-} \rightarrow\left[\mathrm{Cr}(\mathrm{II}) \mathrm{L}\left(\mathrm{H}_{2} \mathrm{O}\right)_{5}\right]^{+}} \\
& {\left[\mathrm{Cr}(\mathrm{II}) \mathrm{L}\left(\mathrm{H}_{2} \mathrm{O}\right)_{5}\right]^{+}+2 \mathrm{e}^{-} \rightarrow \mathrm{Cr}^{0}+5 \mathrm{H}_{2} 0+\mathrm{L}^{-}} \\
& 2 \mathrm{H}^{+}+2 \mathrm{e}^{-} \rightarrow \mathrm{H}_{2}(\mathrm{~g})
\end{aligned}
$$

The intermediate divalent chromium complex is of great significance during the deposition process. ${ }^{14,15}$ Due to the high $\mathrm{pH}$ values in the vicinity of the cathode, the coordinated water molecules of the divalent chromium complex could be partially converted to $\mathrm{OH}$ groups (eq 6). In such a situation, the metal electrodeposition proceeds with the participation of the electroactive hydroxo-complex of divalent chromium (eq 7). ${ }^{44}$ However, long-term electrolysis gives rise to excessive formation of an unstable hydroxo-complex of divalent chromium (i.e., $\left.\left[\mathrm{Cr}(\mathrm{II}) \mathrm{L}\left(\mathrm{H}_{2} \mathrm{O}\right)_{4} \mathrm{OH}\right]\right)$, which can be easily converted into a hydroxo-bridged dimer through olation reaction (eq 8). Once the oligomers are formed, the reaction can go

$$
2\left[\mathrm{Cr}(\mathrm{II}) \mathrm{L}\left(\mathrm{H}_{2} \mathrm{O}\right)_{4} \mathrm{OH}\right] \rightarrow\left[\mathrm{L}\left(\mathrm{H}_{2} \mathrm{O}\right)_{3} \mathrm{Cr}(\mathrm{II}) \mathrm{Cr}(\mathrm{II})\left(\mathrm{H}_{2} \mathrm{O}\right)_{3} \mathrm{~L}\right]+2 \mathrm{H}_{2} \mathrm{O}
$$

further to produce inert polymers of higher molecular weight which act as a barrier that hinders the deposition process. ${ }^{16,48}$ Therefore, it is reasonable to speculate that the suppression of nonelectroactive intermediate of divalent chromium may be the critical factor in sustained deposition of chromium. To shed light on the effects of different complexing agents on the redox abilities of intermediate chromium(II) complexes, DFT calculations were performed.

$$
\begin{aligned}
& {\left[\mathrm{Cr}(\mathrm{II}) \mathrm{L}\left(\mathrm{H}_{2} \mathrm{O}\right)_{5}\right]^{+} \rightarrow\left[\mathrm{Cr}(\mathrm{II}) \mathrm{L}\left(\mathrm{H}_{2} \mathrm{O}\right)_{4} \mathrm{OH}\right]+\mathrm{H}^{-}} \\
& {\left[\mathrm{Cr}(\mathrm{II}) \mathrm{L}\left(\mathrm{H}_{2} \mathrm{O}\right)_{4} \mathrm{OH}+2 \mathrm{e}^{-} \rightarrow \mathrm{Cr}^{0}+4 \mathrm{H}_{2} \mathrm{O}+\mathrm{L}^{-}+\mathrm{OH}^{-}\right.}
\end{aligned}
$$

The optimized geometrical structures of divalent chromium complexes and the corresponding visual HOMOs are shown in Figure 4a. Unlike the octahedral geometry of the sixcoordinated $\mathrm{Cr}$ (III) complex, the $\mathrm{Cr}$ (II) atoms are five coordinated and present the geometry of a distorted trigonal bipyramid. In the $\mathrm{Cr}(\mathrm{II})$ complexes of $\left[\mathrm{Cr}(\mathrm{O} A-H)\left(\mathrm{H}_{2} \mathrm{O}\right)_{5}\right]^{+}$, $\left[\mathrm{Cr}(\mathrm{TA}-\mathrm{H})\left(\mathrm{H}_{2} \mathrm{O}\right)_{5}\right]^{+}$, and $\left[\mathrm{Cr}(U-H)\left(\mathrm{H}_{2} \mathrm{O}\right)_{5}\right]^{2+}$, the organic ligands (oxalate, tartrate, and urea) bind to the metal center in a bidentate fashion, with three water molecules taking part in the coordination. In the case of formic acid, $\mathrm{Cr}(\mathrm{II})$ ion coordinates with one monodentate formate ligand and four water molecules to form the $\left[\mathrm{Cr}(F A-H)\left(\mathrm{H}_{2} \mathrm{O}\right)_{5}\right]^{+}$complex. The calculated distances between the uncoordinated water molecules and the $\mathrm{Cr}$ (II) ion are all larger than $3 \AA$, implying negligible complexation abilities toward $\mathrm{Cr}$ (II). The HOMOs of five-coordinated $\mathrm{Cr}$ (II) complexes are mainly contributed by the $\mathrm{dz}^{2}$ orbitals of chromium and the $2 \mathrm{p}$ orbitals of the coordinated oxygen, leading to $\mathrm{dsp}^{3}$ hybridization and a distorted trigonal bipyramid. 
To evaluate the electron-accepting ability of the divalent chromium complexes, vertical electron affinity (VEA) and adiabatic electron affinity (AEA) analysis has also been carried out based on the optimized geometries. ${ }^{49,50}$ VEA is calculated as the energy difference between the cationic and neutral chromium species with both at the optimized geometry of the cations (E1 - E2), while AEA is calculated as the energy difference between the cationic and neutral chromium species at their respective optimized geometries (E1 - E3) (Figure 4c). The calculated VEA and AEA are all positive (Table S4), indicating that the neutral species is lower in energy than the corresponding cationic species, hence the divalent chromium complexes are unstable and prone to accepting electrons. Moreover, $\left[\mathrm{Cr}(\mathrm{OA}-\mathrm{H})\left(\mathrm{H}_{2} \mathrm{O}\right)_{5}\right]^{+}$and $\left[\mathrm{Cr}(T A-H)\left(\mathrm{H}_{2} \mathrm{O}\right)_{5}\right]^{+}$have higher values of VEA and AEA, thus a stronger ability to accept electrons and can be more easily reduced on the cathode. The fast electroreduction of $\mathrm{Cr}$ (II) in the bath containing oxalic acid or tartaric acid may effectively reduce the generation of chromium(II) hydroxo-complexes which have an adverse effect on sustained electrodeposition by formation of dimers or polymers (eq 8).

As discussed above, the long-term electrolysis often leads to deactivation of chromium(II) complexes. The effects of hydrogen evolution reaction and associated $\mathrm{pH}$ change on redox abilities of chromium(II) complexes need to be taken into account. At high $\mathrm{pH}$, the divalent chromium complexes of $\left[\mathrm{Cr}(\mathrm{OA}-\mathrm{H})\left(\mathrm{H}_{2} \mathrm{O}\right)_{5}\right]^{+},\left[\mathrm{Cr}(\mathrm{TA}-\mathrm{H})\left(\mathrm{H}_{2} \mathrm{O}\right)_{5}\right]^{+}$, $\left[\mathrm{Cr}(F A-H)-\left(\mathrm{H}_{2} \mathrm{O}\right)_{5}\right]^{+}$, and $\left[\mathrm{Cr}(U-H)\left(\mathrm{H}_{2} \mathrm{O}\right)_{5}\right]^{2+}$ tend to lose a proton to form new intermediate species (denoted as $\left[\mathrm{Cr}(\mathrm{OA})-\left(\mathrm{H}_{2} \mathrm{O}\right)_{5}\right], \quad\left[\mathrm{Cr}(\mathrm{TA})\left(\mathrm{H}_{2} \mathrm{O}\right)_{5}\right], \quad[\mathrm{Cr}(\mathrm{FA}-\mathrm{H})$ $\left.\left.\mathrm{H}_{2} \mathrm{O}\right)_{4} \mathrm{OH}\right]$, and $\left[\mathrm{Cr}(\mathrm{U}-\mathrm{H})\left(\mathrm{H}_{2} \mathrm{O}\right)_{4} \mathrm{OH}\right]^{+}$, respectively). Their optimized geometrical structures and corresponding visual HOMOs are shown in Figure 4b. Protons are preferentially lost from the organic ligand $\left(\mathrm{OA}-\mathrm{H}\right.$ and TA-H) in the $\left[\mathrm{Cr}(\mathrm{OA}-\mathrm{H})\left(\mathrm{H}_{2} \mathrm{O}\right)_{5}\right]^{+}$ and $\left[\mathrm{Cr}(\mathrm{TA}-\mathrm{H})\left(\mathrm{H}_{2} \mathrm{O}\right)_{5}\right]^{+}$complexes. In the case of $\left[\mathrm{Cr}(\mathrm{FAH})\left(\mathrm{H}_{2} \mathrm{O}\right)_{5}\right]^{+}$and $[\mathrm{Cr}(\mathrm{U}-\mathrm{H})$ $\left.\left(\mathrm{H}_{2} \mathrm{O}\right)_{5}\right]^{2+}$ complexes, coordinated water molecules lose a proton to generate a $\mathrm{OH}$ ligand. Thus, the hydroxo-complexes (i.e., $\left[\mathrm{Cr}(\mathrm{FA}-\mathrm{H})\left(\mathrm{H}_{2} \mathrm{O}\right)_{4} \mathrm{OH}\right]$ and $\left.\left[\mathrm{Cr}(\mathrm{U}-\mathrm{H})\left(\mathrm{H}_{2} \mathrm{O}\right)_{4} \mathrm{OH}\right]^{+}\right)$can be largely generated in the bath containing formic acid or urea with the increase of $\mathrm{pH}$ value. The deprotonation products of $\left[\mathrm{Cr}(\mathrm{OA})\left(\mathrm{H}_{2} \mathrm{O}\right)_{5}\right],\left[\mathrm{Cr}(\mathrm{TA})\left(\mathrm{H}_{2} \mathrm{O}\right)_{5}\right]$, and $[\mathrm{Cr}(\mathrm{FA}-\mathrm{H})$ $\left(\mathrm{H}_{2} \mathrm{O}\right)_{4} \mathrm{OH}$ ] maintain the five-coordinated distorted trigonal bipyramid configuration. However, as shown in Figure S5, different from the five coordinated $\left[\mathrm{Cr}(\mathrm{U}-\mathrm{H})\left(\mathrm{H}_{2} \mathrm{O}\right)_{5}\right]^{2+}$ complex, the $\mathrm{Cr}(\mathrm{II})$ ion in the $\left[\mathrm{Cr}(\mathrm{U}-\mathrm{H})\left(\mathrm{H}_{2} \mathrm{O}\right)_{4} \mathrm{OH}\right]^{+}$complex is four-coordinated with one monodentate urea ligand, one hydroxyl ligand, and two water molecules, which presents the geometry of square planar with $\mathrm{dsp}^{2}$ hybridization. Its HOMOs are mainly contributed by the $\mathrm{d}\left(x^{2}-y^{2}\right)$ orbitals of chromium and the $2 \mathrm{p}$ orbitals of the coordinated oxygen. 
The calculated VEA values of divalent chromium complexes before and after losing a proton are summarized in Figure $4 \mathrm{~d}$ and Table S4. In comparison to $\left[\mathrm{Cr}(\mathrm{L}-\mathrm{H})\left(\mathrm{H}_{2} \mathrm{O}\right)_{5}\right]^{n}(\mathrm{~L}$ represents OA, TA, FA, or $\mathrm{U}, n=1$ or 2$)$, the corresponding $\left[\mathrm{Cr}(\mathrm{L})\left(\mathrm{H}_{2} \mathrm{O}\right)_{5}\right]^{(\mathrm{n}-1)}$ or $[\mathrm{Cr}(\mathrm{L}-$ $\left.\mathrm{H})\left(\mathrm{H}_{2} \mathrm{O}\right)_{4} \mathrm{OH}\right]^{(\mathrm{n}-1)}$ all show a reduced value of VEA, suggesting a lower electronaccepting ability. Thus, the deprotonation products are less electroactive, and their cathodic reduction is more difficult. Furthermore, the formate hydroxo complex (e.g., $\left.\left[\mathrm{Cr}(\mathrm{FA}-\mathrm{H})\left(\mathrm{H}_{2} \mathrm{O}\right)_{4} \mathrm{OH}\right]\right)$ could be largely accumulated and hence the polymerization reaction occurs, which hinders the reduction process of chromium(II). Different from the formate ligand, although the urea hydroxo complex of $\left[\mathrm{Cr}(\mathrm{U}-\mathrm{H})\left(\mathrm{H}_{2} \mathrm{O}\right)_{4} \mathrm{OH}\right]^{+}$exhibits the lowest VEA value, the thickness of $\mathrm{Cr}$ coating from the OA-TA bath is lower than the OA-TA-U bath. This is probably due to the different bonding type of $[\mathrm{Cr}(\mathrm{U}-\mathrm{H})$ $\left.\left(\mathrm{H}_{2} \mathrm{O}\right)_{4} \mathrm{OH}\right]^{+}\left(\mathrm{dsp}^{2}\right.$ hybridization instead of $\left.\mathrm{dsp}^{3}\right)$. The new structure has a more pronounced steric hindrance effect which impedes the formation of hydroxo bridged complex through olation reaction.

Therefore, as shown in Figure 5, there are generally two routes for the electroreduction of $\mathrm{Cr}(\mathrm{II})$ complexes to metallic $\mathrm{Cr}^{0}$ : (i) a direct route through highly electroactive $[\mathrm{Cr}(\mathrm{LH})($ $\left.\left.\mathrm{H}_{2} \mathrm{O}\right)_{5}\right]^{n}$ complexes and (ii) an indirect route through the less electroactive $\left[\mathrm{Cr}(\mathrm{L})\left(\mathrm{H}_{2} \mathrm{O}\right)_{5}\right]^{(n}$ ${ }^{-1)}$ or $\left[\mathrm{Cr}(\mathrm{L}-\mathrm{H})-\left(\mathrm{H}_{2} \mathrm{O}\right)_{4} \mathrm{OH}\right]^{(n-1)}$ complexes. In the traditional bath containing formic acid (Figure 5a), because of the low VEA value of $\left[\mathrm{Cr}(\mathrm{FA}-\mathrm{H})\left(\mathrm{H}_{2} \mathrm{O}\right)_{5}\right]^{+}$and $[\mathrm{Cr}(\mathrm{FA}-\mathrm{H})$ $\left(\mathrm{H}_{2} \mathrm{O}\right)_{4} \mathrm{OH}$ ], chromium- (II) hydroxo complex can be largely generated and accumulated after a few minutes of electrodeposition (route 2), leading to the formation of inert polymers through an olation reaction. Inversely, the adsorbed polymers act as a barrier that dramatically decrease the diffusion of ions from bulk solution to the electrode surface, further hindering the electroreduction of reactive chromium(II) complexes (route 1). As a result, the current efficiency drops and the coating thickness could barely increase. In contrast, in the bath containing the ternary complexing agent (Figure 5b), the adverse olation reactions could be greatly alleviated and thus the diffusion of chromium ions is not conspicuously impeded, which can also be evidenced by the enhanced limiting diffusion current density shown in Figure 3a. At the initial deposition stage (the first 15 min of electroplating in Figure 1b), the electroactive chromium(II) complexes ([Cr(OA$\left.\mathrm{H})\left(\mathrm{H}_{2} \mathrm{O}\right)_{5}\right]^{+},\left[\mathrm{Cr}(\mathrm{TA}-\mathrm{H})\left(\mathrm{H}_{2} \mathrm{O}\right)_{5}\right]^{+}$, and $\left.\left[\mathrm{Cr}(\mathrm{U}-\mathrm{H})\left(\mathrm{H}_{2} \mathrm{O}\right)_{5}\right]^{2+}\right)$ are rapidly reduced through route 1 and the deposition rate of chromium does not decrease. After a period of electroplating (15-30 min of electroplating in Figure 1b), small amounts of deprotonated intermediate products $\left([\mathrm{Cr}(\mathrm{OA})(\mathrm{H} 2 \mathrm{O}) 5],\left[\mathrm{Cr}(\mathrm{TA})\left(\mathrm{H}_{2} \mathrm{O}\right)_{5}\right]\right.$, and $\left.\left[\mathrm{Cr}(\mathrm{U}-\mathrm{H})\left(\mathrm{H}_{2} \mathrm{O}\right)_{4} \mathrm{OH}\right]^{+}\right)$ are also formed through route 2 . These less reactive $\mathrm{Cr}$ (II) complexes cannot accumulate in large quantities because of its moderate electroreduction to metallic chromium. The deposition rate shows a trend of slight decrease in this stage due to the low VEA value of the deprotonated complexes. However, after the long-term electrolysis (30 $\mathrm{min}$ or longer), large amounts of deprotonated complexes would present in the bath due to the increased $\mathrm{pH}$ value. At this point, chromium(II) hydroxo complex could be generated through further deprotonation and harmful polymerization reactions may occur. The electroplating rate becomes extremely slow and the chromium coating virtually stops growing.

It is also observed that thick chromium coating with uniform appearance can be hardly obtained in the trivalent chromium bath just containing a single ligand of oxalic acid, tartaric acid, or urea (Figures S6 and S7). The formation of a less electroactive hydroxocomplex decreases the throwing power and covering power of the bath, resulting in uneven distribution of the cathodic current density. The multicomponent bath such as the OA-TA-U may strengthen the ligand exchange reaction and cause competitive complexation of $\mathrm{Cr}(\mathrm{II})$ with organic ligands and hydroxy ligands, which further suppresses the hydroxo-complex formation upon sustained electroplating. 


\section{CONCLUSIONS}

In summary, a novel trivalent bath comprising oxalic acid, tartaric acid, and urea (OA-TA$\mathrm{U})$ is proposed for electroplating of hard chromium. Shiny metallic coatings with thickness exceeding $30 \mu \mathrm{m}$ can be obtained from the bath, and the current efficiency of $\mathrm{Cr}$ deposition does not significantly decrease during relatively long-term electrolysis. Compared with OA-TA, FA-U, and FA bath, coatings deposited from OA-TA-U solution exhibits advantages in deposition rate, microstructure, hardness, and corrosion resistance. Firstprinciples calculations suggest that rational selection of complexing agents promotes formation of intermediate $\mathrm{Cr}(\mathrm{II})$ complexes with higher value of VEA and AEA. Furthermore, the suppression of formation of nonelectroactive hydroxo bridged complexes is found to be the critical factor in sustained $\mathrm{Cr}$ (III) deposition. In this regard, the ternary complexing agent offers two benefits: (1) reducing the formation of inactive chromium(II) hydroxo-complex because of the competitive complexation between organic and hydroxyl ligands and (2) further inhibiting the olation reaction due to the synergistic steric hindrance effect of chromium(II) hydroxo-complex. This work provides a mechanistic understanding of the $\mathrm{Cr}(\mathrm{III})$ electroreduction process, as well as a practical guidance on electrolyte design for hard chromium plating.

\section{ACKNOWLEDGEMENTS}

This work received financial support from the Science and Technology Bureau of Shenzhen (Grant No. JCYJ20170306171540744) and the Science and Technology Bureau of Ningbo (Grant No. 201501CX-C01006).

\section{CONTENT}

\section{Supporting Information}

Chemical composition of plating baths; corrosion current density and corrosion potential; simulated equivalent circuit parameters; VEA and AEA value of bivalent chromium complexes; Bode and Nyquist plots; SEM and the corresponding optical images of the $\mathrm{Cr}$ coatings.

\section{Figures and Tables}


Table 1. Basic composition of trivalent Cr plating bath

\begin{tabular}{ccc}
\hline Bath composition & Function & Concentration $\left(\mathrm{mol} \cdot \mathrm{L}^{-1}\right)$ \\
\hline Chromium sulfate $\left(\mathrm{Cr}_{2}\left(\mathrm{SO}_{4}\right)_{3} \cdot 6 \mathrm{H}_{2} \mathrm{O}\right)$ & Source of $\mathrm{Cr}$ & 0.4 \\
Sodium sulfate $\left(\mathrm{Na}_{2} \mathrm{SO}_{4}\right)$ & Conducting salt & 0.3 \\
Aluminum sulfate $\left(\mathrm{Al}_{2}\left(\mathrm{SO}_{4}\right)_{3}\right)$ & Conducting salt & 0.15 \\
Boric acid $\left(\mathrm{H}_{3} \mathrm{BO}_{3}\right)$ & Buffer agent & 0.65 \\
Oxalic acid $\left(\mathrm{H}_{2} \mathrm{C}_{2} \mathrm{O}_{4}\right)$ & Complexing agent & 0.25 \\
Tartaric acid $\left(\mathrm{C}_{4} \mathrm{H}_{6} \mathrm{O}_{6}\right)$ & Complexing agent & 0.15 \\
Urea $\left(\mathrm{CH}_{4} \mathrm{~N}_{2} \mathrm{O}\right)$ & Complexing agent & 0.3 \\
\hline
\end{tabular}

(a)

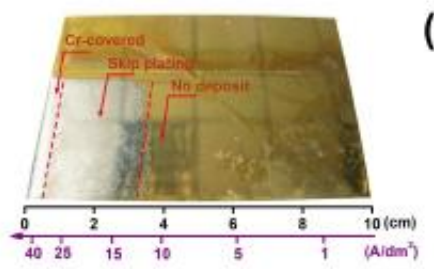

(b)

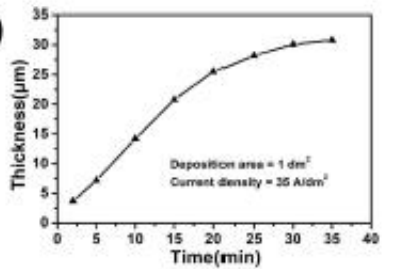

(c)

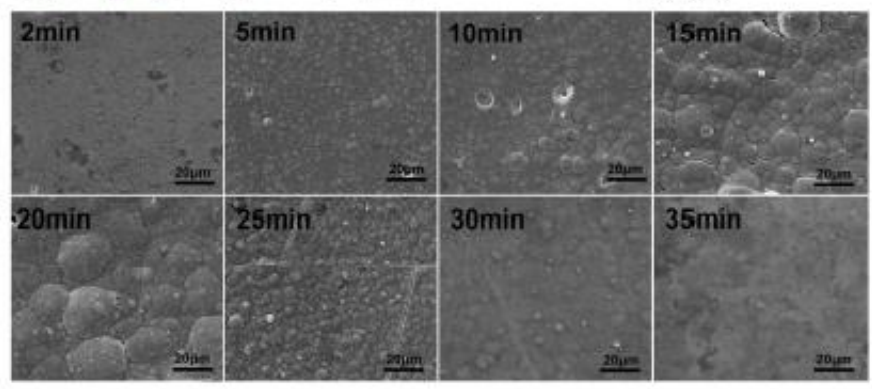

(d)

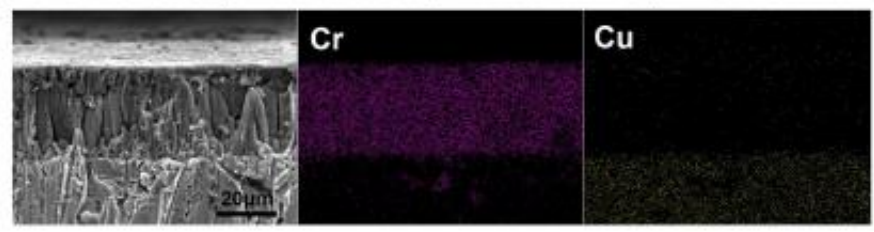

Figure 1. Electrodeposition of hard chromium coating from trivalent chromium bath containing the ternary complexing agent. (a) Determination of the optimum current density range of the plating bath by Hull cell test. (b) Correlation of $\mathrm{Cr}$ coating thickness with deposition time. (c) SEM images of chromium coatings obtained at $35 \mathrm{~A} / \mathrm{dm}^{2}$ with different deposition time. (d) Cross-section microstructure and the corresponding $\mathrm{Cr}$ and $\mathrm{Cu}$ elemental mapping images of the chromium coating obtained at deposition time of $30 \mathrm{~min}$. 
Table 2. Comparison of the main characteristics of different trivalent chromium baths and the resulting $\mathrm{Cr}$ coatings.

\begin{tabular}{ccccccc}
\hline Solution & $\begin{array}{c}\text { Current } \\
\text { density } \\
\left(\mathrm{A} / \mathrm{dm}^{2}\right)\end{array}$ & $\begin{array}{c}\text { Deposition } \\
\text { time } \\
(\mathrm{min})\end{array}$ & $\begin{array}{c}\text { Coating } \\
\text { Thickness } \\
(\mu \mathrm{m})\end{array}$ & $\begin{array}{c}\text { Coating } \\
\text { Hardness } \\
(\mathrm{HV})\end{array}$ & $\begin{array}{c}\text { Deposition } \\
\text { rate } \\
(\mu \mathrm{m} / \mathrm{min})\end{array}$ & $\begin{array}{c}\text { Current } \\
\text { efficiency } \\
(\%)\end{array}$ \\
\hline OA-TA-U & 35 & 30 & 30.2 & 866 & 1.01 & 19.18 \\
OA-TA & 45 & 30 & 20.9 & 792 & 0.70 & 10.33 \\
FA-U & 20 & 30 & 25.3 & 630 & 0.84 & 28.12 \\
FA & 5 & 10 & $<1$ & - & $<0.1$ & - \\
\hline
\end{tabular}

(a)

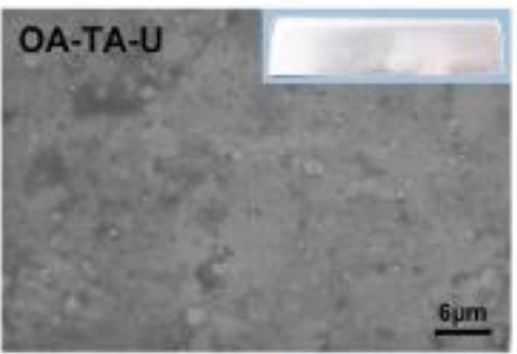

(c)

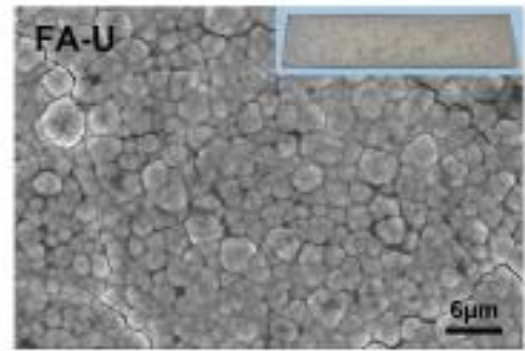

(e)

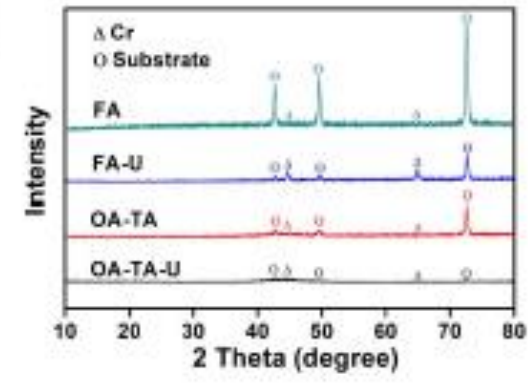

(b)

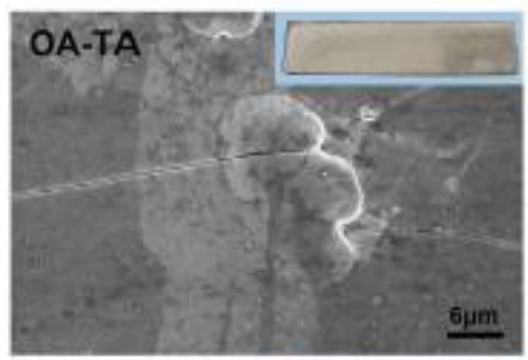

(d)

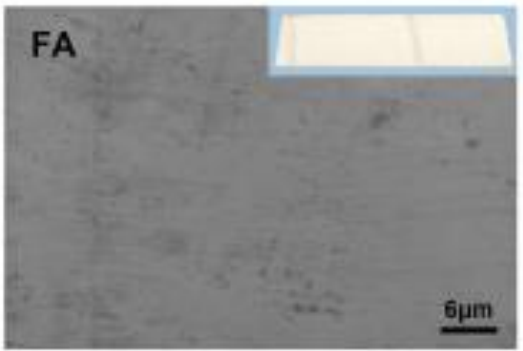

(f)

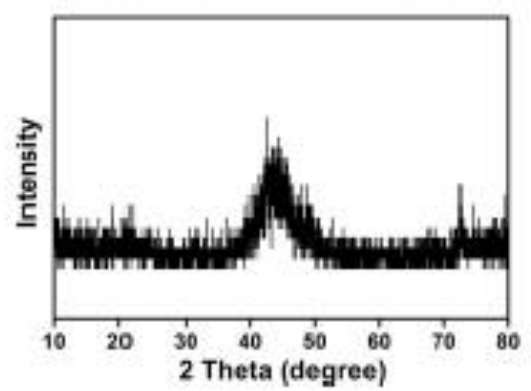

Figure 2. Morphology and composition characterization of chromium coatings. SEM and the corresponding optical images (inset) of the Cr coatings obtained from (a) OA-TA-U bath, (b) OA-TA bath, (c) FA-U bath, and (d) FA bath. (e) X-ray diffraction patterns of $\mathrm{Cr}$ coatings deposited from different baths. (f) The magnified XRD spectrum of OA-TA-U in (e). 
(a)

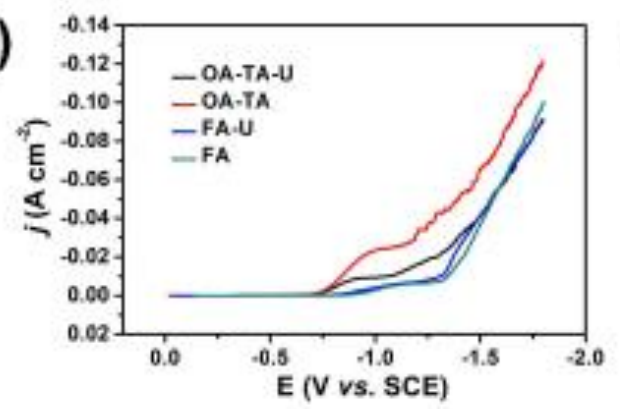

(c)

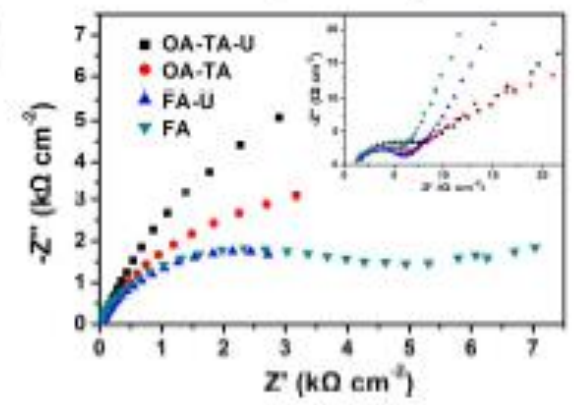

(b)

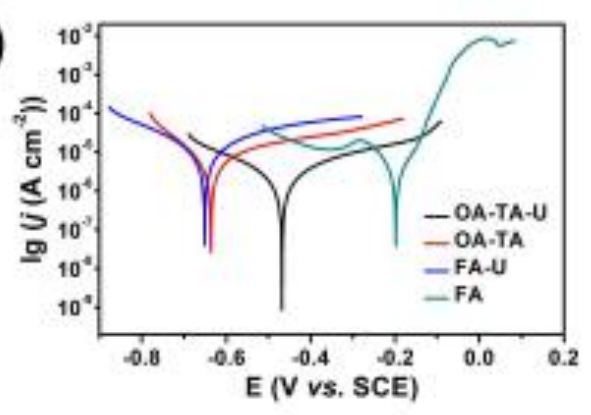

(d)

(e)
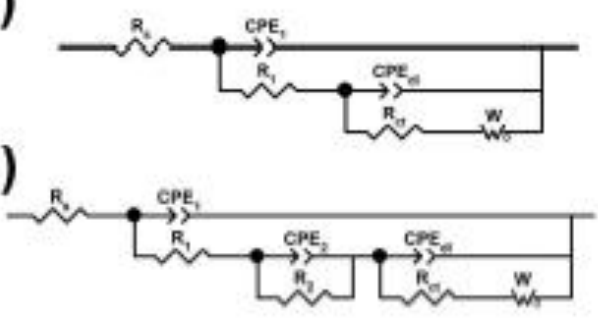

Figure 3. Electrochemical characterization of the plating solutions and the chromium coatings. (a) LSV curves of chromium electrodeposition from different baths. (b) Tafel plots and (c) Nyquist plots of the chromium coatings deposited from different baths. Equivalent circuits of impedance behavior of the chromium coatings electrodeposited from the (d) FA bath and (e) OA-TA-U, OA-TA, and FA-U baths. Both the Tafel curves and impedance measurements were conducted in $3.5 \% \mathrm{NaCl}$ solution at room temperature. 
(a)
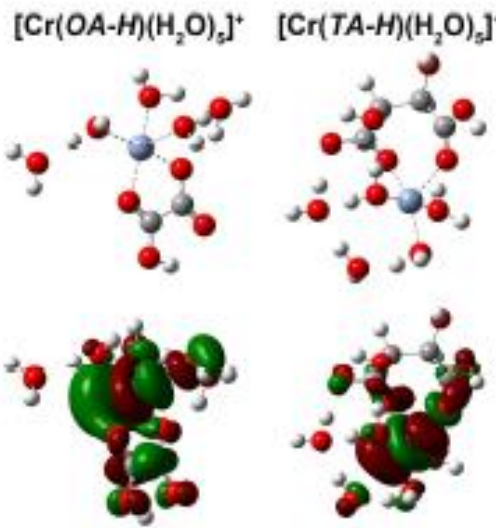

(b) $\left[\mathrm{Cr}(\mathrm{OA})\left(\mathrm{H}_{2} \mathrm{O}\right)_{5}\right]$

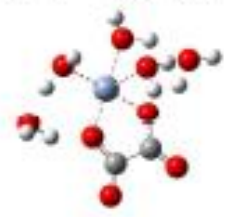

$\left[\mathrm{Cr}(T A)\left(\mathrm{H}_{2} \mathrm{O}\right)\right]$

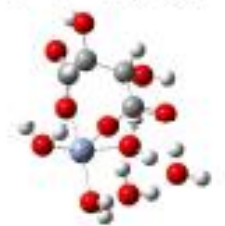

$\left[\mathrm{Cr}(\mathrm{FA}-\mathrm{H})\left(\mathrm{H}_{2} \mathrm{O}\right)_{4} \mathrm{OH}\right] \quad\left[\mathrm{Cr}(\mathrm{U}-\mathrm{H})\left(\mathrm{H}_{2} \mathrm{O}\right)_{4} \mathrm{OH}\right]^{*}$
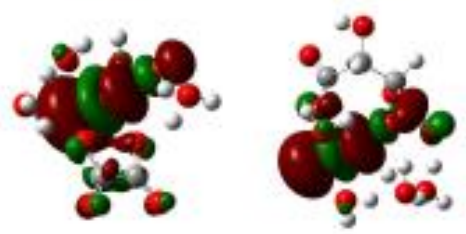

(c)

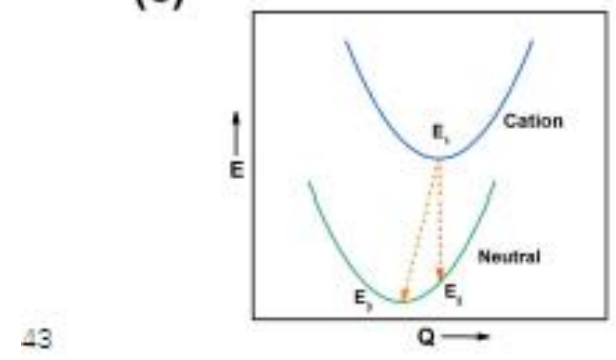

$\left[\mathrm{Cr}(\mathrm{FA}-\mathrm{H})\left(\mathrm{H}_{2} \mathrm{O}\right)\right]^{*}\left[\mathrm{Cr}(\mathrm{U}-\mathrm{H})\left(\mathrm{H}_{2} \mathrm{O}\right)\right]_{]^{2 *}}$
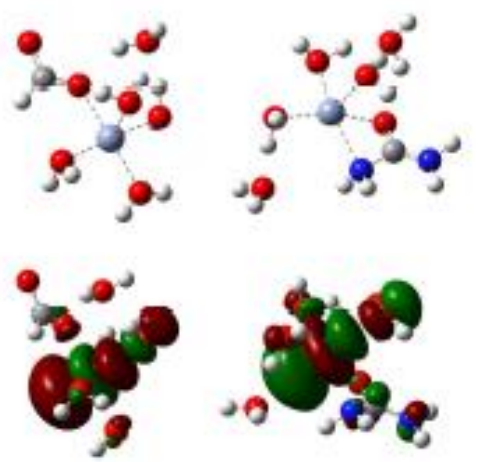

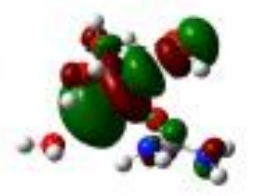

(d)
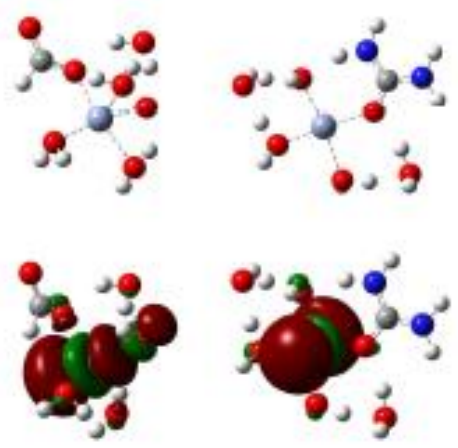

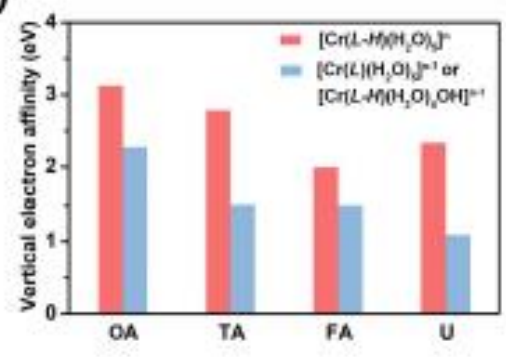

Figure 4. Optimized geometrical structures and visual HOMOs of divalent-Cr complexes of (a) $\left[\mathrm{Cr}(\mathrm{L}-\mathrm{H})\left(\mathrm{H}_{2} \mathrm{O}\right)_{5}\right]^{n}$ and (b) $\left[\mathrm{Cr}(\mathrm{L})\left(\mathrm{H}_{2} \mathrm{O}\right)_{5}\right]^{n-1}$ or $\left[\mathrm{Cr}(\mathrm{L}-\mathrm{H})\left(\mathrm{H}_{2} \mathrm{O}\right)_{4} \mathrm{OH}\right]^{n-1}$, L represents OA, TA, FA, or U, $n=1$ or 2. (c) Schematic diagram for the calculation of vertical electron affinity (E1 - E2) and adiabatic electron affinity (E1 - E3). (d) Summary of vertical electron affinity energy of divalent-Cr complexes before and after losing a proton. 

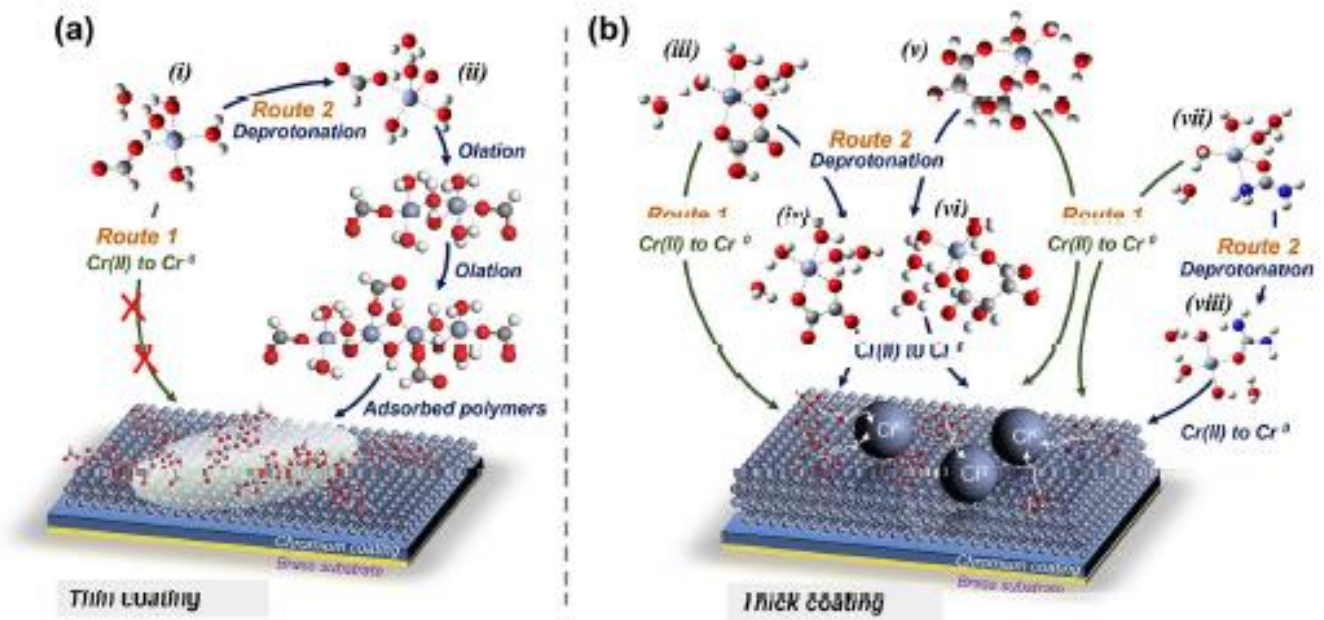

Figure 5. Schematic illustration of electroreduction process of chromium(II) complexes in trivalent chromium bath containing (a) a formic acid complexing agent and (b) a ternary complexing agent. (i) $\left[\mathrm{Cr}(\mathrm{FA}-\mathrm{H})\left(\mathrm{H}_{2} \mathrm{O}\right)_{5}\right]^{+}$, (ii) $\left[\mathrm{Cr}(\mathrm{FA}-\mathrm{H})\left(\mathrm{H}_{2} \mathrm{O}\right)_{4} \mathrm{OH}\right]$, (iii) $\left[\mathrm{Cr}(\mathrm{OA}-\mathrm{H})\left(\mathrm{H}_{2} \mathrm{O}\right)_{5}\right]$ + , (iv) $\left[\mathrm{Cr}(\mathrm{OA})\left(\mathrm{H}_{2} \mathrm{O}\right)_{5}\right]$, (v) $\left[\mathrm{Cr}(\mathrm{TA}-\mathrm{H})\left(\mathrm{H}_{2} \mathrm{O}\right)_{5}\right]^{+}$, (vi) $\left[\mathrm{Cr}(\mathrm{TA})\left(\mathrm{H}_{2} \mathrm{O}\right)_{5}\right]$, (vii) $\left[\mathrm{Cr}(\mathrm{U}-\mathrm{H})\left(\mathrm{H}_{2} \mathrm{O}\right)_{5}\right]^{2}$ + , and (viii) $\left[\mathrm{Cr}(\mathrm{U}-\mathrm{H})\left(\mathrm{H}_{2} \mathrm{O}\right)_{4} \mathrm{OH}\right]^{+}$.

\section{For Table of Contents Only}
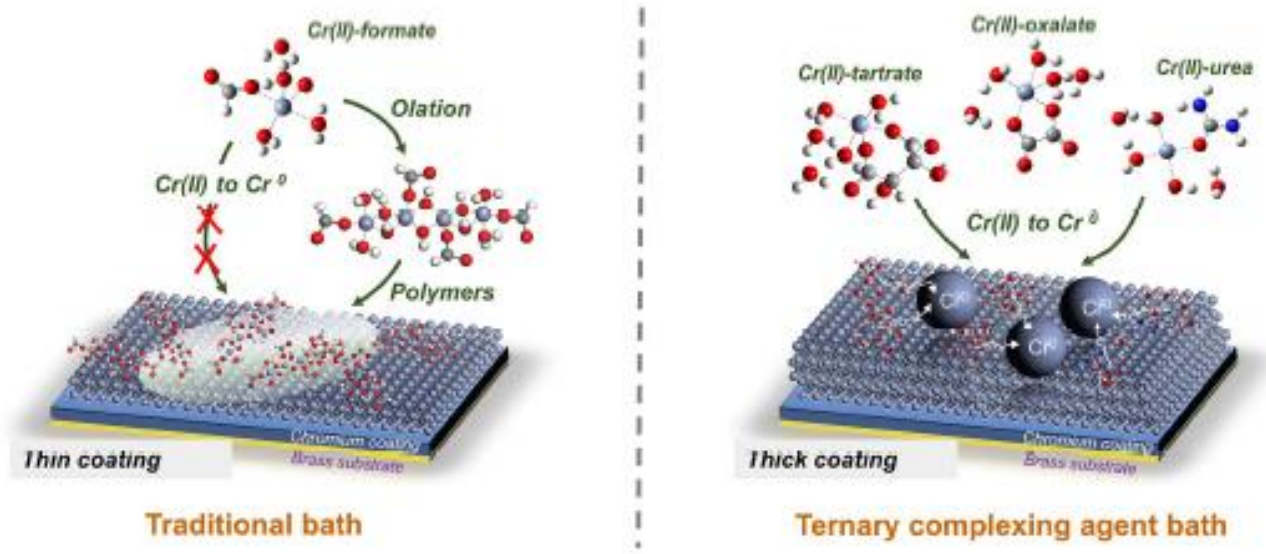

\section{REFERENCES}

(1) Saghi Beyragh, M.R.; Khameneh Asl, S.; Norouzi, S. A comparative research on corrosion behavior of a standard, crackfree and duplex hard chromium coatings. Surf. Coat. Technol. 2010,

205 (7), 2605-2610. 
(2) Lindsay, J. H. Decorative \& hard chromium plating. Plat. Surf. Finish. 2003, 90 (8), 22-24.

(3) Fedrizzi, L.; Rossi, S.; Bellei, F.; Deflorian, F. Wear-corrosion mechanism of hard chromium coatings. Wear 2002, 253 (11-12), 1173-1181.

(4) Schlesinger, M.; Paunovic, M. Modern electroplating; John Wiley \& Sons: New York, 2011.

(5) Protsenko, V. S.; Danilov, F. I.; Gordiienko, V. O.; Kwon, S. C.; Kim, M.; Lee, J. Y. Electrodeposition of hard nanocrystalline chrome from aqueous sulfate trivalent chromium bath. Thin Solid Films 2011, 520 (1), 380-383.

(6) Hua, L.; Chan, Y. C.; Wu, Y.; Wu, B. The determination of hexavalent chromium (Cr6+) in electronic and electrical components and products to comply with RoHS regulations. J. Hazard. Mater.

2009, 163 (2-3), 1360-1368.

(7) Baral, A.; Engelken, R. D. Chromium-based regulations and greening in metal finishing industries in the USA. Environ. Sci. Policy 2002, 5 (2), 121-133.

(8) Giovanardi, R.; Orlando, G. Chromium electrodeposition from Cr(III) aqueous solutions. Surf. Coat. Technol. 2011, 205 (15), 3947- 3955.

(9) Baral, A.; Engelken, R. Modeling, optimization, and comparative analysis of trivalent chromium electrodeposition from aqueous glycine and formic acid baths. J. Electrochem. Soc. 2005, 152 (7), C504-C512.

(10) Song, Y. B.; Chin, D. T. Current efficiency and polarization behavior of trivalent chromium electrodeposition process. Electrochim. Acta 2002, 48 (4), 349-356.

(11) Mahdavi, S.; Allahkaram, S. R.; Heidarzadeh, A. Characteristics and properties of Cr coatings electrodeposited from $\mathrm{Cr}(\mathrm{III})$ baths. Mater. Res. Express 2019, 6 (2), 026403.

(12) Liang, A.; Li, Y.; Liang, H.; Ni, L.; Zhang, J. A favorable chromium coating electrodeposited from Cr(III) electrolyte reveals anti-wear performance similar to conventional hard chromium. Mater. Lett. 2017, 189, 221-224.

(13) Leimbach, M.; Tschaar, C.; Schmidt, U.; Bund, A. Electrochemical characterization of chromium deposition from trivalent solutions for decorative applications by EQCM and near-surface pH measurements. Electrochim. Acta 2018, 270, 104-109.

(14) Protsenko, V.; Danilov, F. Kinetics and mechanism of chromium electrodeposition from formate and oxalate solutions of Cr(III) compounds. Electrochim. Acta 2009, 54 (24), 5666-5672.

(15) Phuong, N. V.; Kwon, S.-C.; Lee, J.-Y.; Shin, J.; Huy, B. T.; Lee, Y.-I. Mechanistic study on the effect of PEG molecules in a trivalent chromium electrodeposition process. Microchem. J. 2011, 99 (1), 7- 14.

(16) Mandich, N. Chemistry \& Theory of Chromium Deposition: Part 1-Chemistry. Plat. Surf. Finish. 1997, 84 (5), $108-115$.

(17) Abbott, A. P.; Ryder, K. S.; Konig, U. Electrofinishing of metals using eutectic based ionic liquids. Trans. Inst. Met. Finish. 2008, 86(4), 196-204.

(18) He, X.; Hou, B.; Li, C.; Zhu, Q.; Jiang, Y.; Wu, L. Electrochemical mechanism of trivalent chromium reduction in 1-butyl-3-methylimidazolium bromide ionic liquid. Electrochim. Acta 2014, 130, 245-252.

(19) Eugenio, S.; Rangel, C. M.; Vilar, R.; Quaresma, S. Electrochemical aspects of black chromium electrodeposition from 1-butyl-3-methylimidazolium tetrafluoroborate ionic liquid. Electrochim. Acta 2011, 56 (28), 10347-10352.

(20) Ferreira, E. S. C.; Pereira, C. M.; Silva, A. F. Electrochemical studies of metallic chromium electrodeposition from a Cr(III) bath. J. Electroanal. Chem. 2013, 707, 52-58.

(21) Zeng, Z.; Wang, L.; Liang, A.; Zhang, J. Tribological and electrochemical behavior of thick Cr-C alloy coatings electrodeposited in trivalent chromium bath as an alternative to conventional Cr coatings. Electrochim. Acta 2006, 52 (3), 1366-1373.

(22) Huang, C. A.; Lin, C. K.; Chen, C. Y. Hardness variation and corrosion behavior of as-plated and annealed Cr-Ni alloy deposits electroplated in a trivalent chromium-based bath. Surf. Coat. Technol. 2009, 203 (24), 3686-3691.

(23) Mahdavi, S.; Allahkaram, S. Composition, characteristics and tribological behavior of $\mathrm{Cr}, \mathrm{Co}-\mathrm{Cr}$ and $\mathrm{Co}-\mathrm{Cr} / \mathrm{TiO}_{2}$ nano-composite coatings electrodeposited from trivalent chromium based baths. J. Alloys Compd. 2015, 635, 150

-157 .

(24) Ghaziof, S.; Golozar, M. A.; Raeissi, K. Characterization of asdeposited and annealed Cr-C alloy coatings produced from a trivalent chromium bath. J. Alloys Compd. 2010, 496 (1-2), 164-168.

(25) Fang, J. Electroplating of Multicomponent Complex; Defense Industry Press: Beijing, 1983.

(26) Fang, J. Theory \& application of coordination compounds in electroplating; Chemical Industry Press: Beijing, 2007.

(27) Jung, M.; Lee, G.; Choi, J. Electrochemical plating of $\mathrm{Cu}-\mathrm{Sn}$ alloy in non-cyanide solution to substitute for $\mathrm{Ni}$ undercoating layer. Electrochim. Acta 2017, 241, 229-236.

(28) Cui, G.; Li, N.; Li, D.; Chi, M. Study of optimized complexing agent for low-phosphorus electroless nickel plating bath. J. Electrochem. Soc. 2005, 152 (10), C669-C674.Tsuji, K.; Nishikawa, T.; Takeuchi, T.; Obata, K.; Nawafune, H. Silver and silver alloy plating bath. US 7938948 B2, 2011.

(29) Cordonier, C.; Honma, H. Non-cyanide gold plating bath and method for preparing non-cyanide gold plating bath. US 9719183 B2, 2017.

(30) Sun, J.; Li, A.; Li, Z.; Peng, B. Electroplating method and electroplated product. US 8147671 B2, 2012.

(31) Surviliene, S.; Nivinskiene, O.; Cesuniene, A.; Selskis, A. Effect of $\mathrm{Cr}(\mathrm{III})$ solution chemistry on

electrodeposition of chromium. J. Appl. Electrochem. 2006, 36 (6), 649-654. 
(33) Surviliene, S.; Jasulaitiene, V.; Nivinskiene, O.; Cesuniene, A. Effect of hydrazine and hydroxylaminophosphate on chrome plating from trivalent electrolytes. Appl. Surf. Sci. 2007, 253 (16), 6738- 6743.

(34) Danilov, F. I.; Protsenko, V. S.; Gordiienko, V. O.; Kwon, S. C.; Lee, J. Y.; Kim, M. Nanocrystalline hard chromium electrodeposition from trivalent chromium bath containing carbamide and formic acid: Structure, composition, electrochemical corrosion behavior, hardness and wear characteristics of deposits. Appl. Surf. Sci. 2011, 257 (18), 8048-8053.

(35) Zeng, Z.; Sun, Y.; Zhang, J. The electrochemical reduction mechanism of trivalent chromium in the presence of formic acid. Electrochem. Commun. 2009, 11 (2), 331-334.

(36) Zeng, Z.; Zhang, Y.; Zhao, W.; Zhang, J. Role of complexing ligands in trivalent chromium electrodeposition. Surf. Coat. Technol. 2011, 205 (20), 4771-4775.

(37) Del Pianta, D.; Frayret, J.; Gleyzes, C.; Cugnet, C.; Dupin, J. C.; Le Hecho, I. Determination of the chromium(III) reduction mechanism during chromium electroplating. Electrochim. Acta 2018, 284, 234-241.

(38) Miyake, M.; Kubo, Y.; Hirato, T. Hull cell tests for evaluating the effects of polyethylene amines as brighteners in the electrodeposition of aluminum from dimethylsulfone- $\mathrm{AlCl}_{3}$ baths. Electrochim. Acta 2014, 120, 423-428.

(39) Protsenko, V. S.; Danilov, F. I. Chromium electroplating from trivalent chromium baths as an environmentally friendly alternative to hazardous hexavalent chromium baths: comparative study on advantages and disadvantages. Clean Technol. Environ. Policy 2014, 16 (6), 1201-1206.

(40) Drela, I.; Szynkarczuk, J.; Kubicki, J. Electrodeposition of chromium from Cr (III) electrolytes in the presence of formic acid. J. Appl. Electrochem. 1989, 19 (6), 933-936.

(41) Szynkarczuk, J.; Drela, I.; Kubicki, J. Electrochemical behaviour of chromium (III) in the presence of formic acid I. Electrochim. Acta 1989, 34 (3), 399-403.

(42) Chien, C.; Liu, C.; Chen, F.; Lin, K.; Lin, C. Microstructure and properties of carbon-sulfur-containing chromium deposits electroplated in trivalent chromium baths with thiosalicylic acid. Electrochim. Acta 2012, 72, 74-80.

(43) Polukarov, Y. M.; Safonov, V.; Edigaryan, A.; Vykhodtseva, L. Chrome Plating from Sulfate-Oxalate Cr (III) Baths. Structure, Composition, and Corrosion Behavior1. Prot. Met. 2001, 37 (5), 447-451.

(44) Phuong, N. V.; Kwon, S. C.; Lee, J. Y.; Lee, J. H.; Lee, K. H. The effects of pH and polyethylene glycol on the Cr(III) solution chemistry and electrodeposition of chromium. Surf. Coat. Technol. 2012, 206 (21), 4349-4355.

(45) Yu, H.; Chen, B.; Wu, H.; Sun, X.; Li, B. Improved electrochemical performance of trivalent-chrome coating on Al 6063 alloy via urea and thiourea addition. Electrochim. Acta 2008, 54 (2), 720-726.

(46) Surviliene, S.; Lisowska-Oleksiak, A.; Selskis, A.; Č̌sǔniene, A. Corrosion behaviour of Cr coatings deposited from $\mathrm{Cr}(\mathrm{III})$ formateurea electrolytes. Trans. Inst. Met. Finish. 2006, 84 (5), 241-245.

(47) Tu, Z.; Yang, Z.; Zhang, J.; An, M.-Z.; Li, W.-L. Cathode polarization in trivalent chromium plating. Plat. Surf. Finish. 1993, 80, 79-79.

(48) Watson, A.; Anderson, A.; El-Sharif, M.; Chisholm, C. The role of chromium II catalysed olation reactions in the sustained deposition of chromium and its alloys from environmentally acceptable chromium III electrolytes. Trans. Inst. Met. Finish. 1991, 69 (1), 26-32.

(49) Siefermann, K. R.; Abel, B. The hydrated electron: a seemingly familiar chemical and biological transient. Angew. Chem., Int. Ed. 2011, 50 (23), 5264-5272.

(50) Rienstra-Kiracofe, J. C.; Tschumper, G. S.; Schaefer, H. F.; Nandi, S.; Ellison, G. B. Atomic and molecular electron affinities: Photoelectron experiments and theoretical computations. Chem. Rev. 2002, 102 (1), 231-282. 